\title{
Relationships between intake of PUFA n-3 fatty acids and their quantitative content in the carcass tissues of pigs*
}

\author{
G. Skiba ${ }^{1}$, S. Raj, M. Wojtasik and D. Weremko \\ The Kielanowski Institute of Animal Physiology and Nutrition, Polish Academy of Sciences, \\ Department of Protein and Energy Metabolism \\ 05-110 Jabtonna, Poland
}

(Received 6 November 2012; revised version; 20 November 2012; accepted 15 November 2012)

\begin{abstract}
The mathematical relation between intake of C18:3 n-3 (linolenic acid, ALA), 20:5 n-3 (eicosapentaenoic acid, EPA), and 22:6 n-3 (docosahexaenoic acid, DHA) acids and their content in the Musculus longissimus dorsi (MLD) and backfat (BF) of pigs growing from 60 to $105 \mathrm{~kg}$ body weight (BW) was investigated. At $60 \mathrm{~kg} \mathrm{BW}, 32$ crossbred pigs were allotted to 4 diets/groups (A, B, $\mathrm{C}$, and $\mathrm{D}$, respectively) and fed isoenergetic and isoprotein diets, where $10 \%$ of metabolizable energy was replaced by fat mixtures for a total of $3.5 \%$ per $\mathrm{kg}$ diet. All feeds had a similar amount of C18:2 n-6 (linoleic acid, LA), but due to the composition of the particular fat mixtures, differed in the amounts of ALA, EPA, and DHA. The ratio of $\Sigma \mathrm{n}-6 / \Sigma \mathrm{n}-3$ was $3.87,4.80,1.77$, and 2.20 in $\operatorname{diets} \mathrm{A}, \mathrm{B}, \mathrm{C}$, and D, respectively. Growth and carcass performance, intramuscular fat, and MUFA and SFA contents in both investigated tissues did not differ among groups. The ALA content ( $\mathrm{g} / 100 \mathrm{~g}$ tissue) and LA:ALA ratio in the MLD and BF of group B pigs differed $(\mathrm{P}<0.01)$ from the remaining groups. The EPA and DHA contents in the MLD did not differ among groups, but the BF was lower $(\mathrm{P}<0.01)$ in A and D compared with B and C pigs. Relationships between ALA intake and its content in BF was stronger than in the MLD and the coefficients of regression (' $b$ ') and correlation (' $r$ ') were $: b=0.127$ and $r=0.85$ for BF, and $b=0.002$ and $r=0.59$ for MLD. For the remaining long-chain n-3 PUFA, a linear relationship between their intake and tissue concentration was found only in $\mathrm{BF}$, where the coefficients of regression and correlation ranged from: $b=0.035$ and $r=0.64$ for EPA and $b=0.089$ to $r=0.89$ for DHA.
\end{abstract}

KEY WORDS: pig, fatty acids, Longissimus dorsi muscle, backfat, carcass

\footnotetext{
* Supported by the Project BIOFOOD - Innovative, Functional Products of Animal Origin No. POIG.01.01.02-014-090/09 co-financed by the European Union from the European Regional Development Fund within the Innovative Economy Operational Programme 2007-2013

${ }^{1}$ Corresponding author: e-mail: g.skiba@ifzz.pan.pl
} 


\section{INTRODUCTION}

It is well known that the fatty acid composition of pork meat and fat is of great importance for human health, as pork constitutes a large part of total meat consumption in western countries. The fatty acids, C18:2 n-6 (linoleic acid, LA) and C18:3 n-3 (linolenic acid, ALA) play a crucial role because they cannot be synthetized de novo by mammals. Both fatty acids must thus be derived directly from the diet. For this reason, the content of these fatty acids in meat and fat tissue reflects their concentration in the feed offered to animals.

In the human diet, the ratio of C18:2 n-6/C18:3 n-3 should be below 4 (WHO/ FAO, 2003). It has been known for a long time that pig tissues, compared with ruminants, have a higher proportion of $\mathrm{C} 18: 2 \mathrm{n}-6$ acid and that the $n-6 / n-3$ ratio does not comply with WHO recommendations (e.g., Enser et al., 1996). It thus seems desirable to increase the concentration of $18: 3 \mathrm{n}-3$ acid, which should significantly improve the C18:2 n-6/C18:3 n-3 ratio. Moreover, C18:3 n-3 acid is a precursor of the long-chain polyunsaturated fatty acids, C20:5 n-3 (eicosapentaenoic acid, EPA) and C22:6 n-3 (docosahexaenoic acid, DHA), which are extremely important for proper growth, for the function of the circulatory and neural systems, and for decreasing the risk of cancer (Simopoulos, 2001). Linseed and linseed oil are rich in C18:3 n-3 acid, whereas fish oil and fish products are rich in C20:5 n-3 and C22:6 n-3 acids. Therefore, pig diets are usually supplemented with linseed/ linseed oil or fish oil to provide fatty acids from the n-3 family (Kouba et al., 2003; Haak et al., 2008). Most research has investigated primarily the influence of fat source on the profile of fatty acids in feed or in animal tissue (e.g., Jaturasitha et al., 2009). There is a little data, however, on the mathematical relation between C18:3 n-3 intake and its profile in body tissues or how intake of this fatty acid influences the tissue profiles of C20:5 n-3 and C22:6 n-3 (Nguyen et al., 2003b; Flachowsky et al., 2008). The cited works concern only the relationship between the intake of these fatty acids or precursors on their profile in a single type of muscle/fat tissue, but not on that between the intake and quantitative content of these fatty acids in muscle and backfat. Presentation of the results in the form of the quantitative fatty acid content in pork and backfat will give information on the amount of fatty acids a particular animal product provides. Moreover, recognition of the relationship between intake and quantitative fatty acid content in animal tissue/products is important from both 'animal nutritionist' and consumer aspects, as meat products are mixtures of various animal muscles and fat tissues.

The aim of this study was to determine the mathematical relationship between linolenic, eicosapentaenoic, and docosahexaenoic acid intakes/contents in feed and their quantitative content in the Musculus longissimus dorsi and backfat of finishing pigs. 


\section{MATERIAL AND METHODS}

All procedures described in this study were conducted after obtaining the approval by the Local Ethics Commission. Some parts of the Material and Methods section were described in Wojtasik et al. (2012).

\section{Animals and diets}

The study was carried out on 38 pigs (barrows:gilts, 1:1) crossbreed of $\widehat{\partial}$ Duroc x $q$ (Danish Landrace x Polish Large White) growing from 25 to $105 \mathrm{~kg}$ body weight (BW). During growth from 25 to $60 \mathrm{~kg} \mathrm{BW}$ all animals consumed a commercial grower diet (13.2 MJ EM and $8.2 \mathrm{~g}$ ileal digestible lysine). At $60 \mathrm{~kg}$ BW, six animals were slaughtered (group ' 0 '), the remaining ( $\mathrm{n}=32$ ) were allotted into 4 groups ( 8 animals each) and fed from 60 to $105 \mathrm{~kg} \mathrm{BW}$ four experimental diets compounded with barley, maize, wheat, soyabean meal and rapeseed meal. In each diet, $10 \%$ of metabolizable energy was replaced by $3.5 \%$ of a fat mixture that introduced into the diets different ratios of fatty acids. The fat mixture contained either rapeseed oil and linseed oil (diet/group A), rapeseed oil, fish oil and lard (diet/group B), linseed oil and fish oil (diet/group C), rapeseed oil, linseed oil and lard (diet/group D). The addition of lard to diets B and D allowed obtaining similar levels of saturated fatty acids (SFA) as in the remaining diets. The diets had similar C18:2 n-6 contents, but different C18:3 n-3 (10.13\%, 4.63\%, 16.46\%, and $16.05 \%$, respectively, in diets A, B, C, and D), C20:5 n-3 (0.0\%, $0.23 \%, 0.18 \%$, and $0.04 \%$, respectively, in diets $\mathrm{A}, \mathrm{B}, \mathrm{C}$, and $\mathrm{D})$, and $\mathrm{C} 22: 6 \mathrm{n}-3$ concentrations $(0.0 \%, 1.86 \%, 1.42 \%$, and $0.28 \%$, respectively, in diets $\mathrm{A}, \mathrm{B}, \mathrm{C}$, and $\mathrm{D})$. The ingredients and determined chemical composition, contents of metabolizable energy (ME) and fatty acids (FA) are presented in Tables 1 and 2.

\section{Sample collecton and analysis}

The animals were electrically stunned then slaughtered at 60 (group ' 0 ') and at approximately $105 \mathrm{~kg} \mathrm{BW}$ (experimental pigs). Forty-five min after slaughter, the $\mathrm{pH}$ of musculus Longissimus dorsi (MLD) was measured 3 times $\left(\mathrm{pH}_{45}\right)$ using a STAR pH-meter Matthäus (Germany). After $24 \mathrm{~h}$ of chilling the carcass at $4^{\circ} \mathrm{C}$, the $\mathrm{pH}$ of the MLD was measured again $\left(\mathrm{pH}_{24}\right)$.

Representative samples of the MLD and backfat (BF) were taken for determination of chemical composition (AOAC, 2005) and fatty acids (Folch et al., 1957). The total content of fatty acids was calculated as $90 \%$ of ether extract (Kratz, 2003). The concentration of fatty acids in the investigated tissues was expressed in g per $100 \mathrm{~g}$ tissue. 
Table 1. Composition and nutritive value of experimental diets, $\mathrm{g} \cdot \mathrm{kg}^{-1}$

\begin{tabular}{|c|c|c|c|c|}
\hline \multirow{2}{*}{ Indices } & \multicolumn{4}{|c|}{ Diet } \\
\hline & A & $\mathrm{B}$ & $\mathrm{C}$ & $\mathrm{D}$ \\
\hline \multicolumn{5}{|l|}{ Component } \\
\hline barley & 360 & 360 & 360 & 360 \\
\hline wheat & 360 & 360 & 360 & 360 \\
\hline maize & 100 & 100 & 100 & 100 \\
\hline rapeseed meal (31\% cp) & 40 & 40 & 40 & 40 \\
\hline soyabean meal $(44 \% \mathrm{cp})$ & 80 & 80 & 80 & 80 \\
\hline rapeseed oil & 25 & 10 & - & 10 \\
\hline linseed oil & 10 & - & 25 & 23 \\
\hline fish oil (cod) & - & 20 & 10 & - \\
\hline lard & & 5 & - & 2 \\
\hline premix $^{1}$ & 25 & 25 & 25 & 25 \\
\hline \multicolumn{5}{|l|}{ Chemical composition (determined) } \\
\hline dry matter & 892 & 889 & 887 & 886 \\
\hline ash & 41 & 41 & 41 & 41 \\
\hline organic matter & 851 & 848 & 746 & 743 \\
\hline crude protein & 172 & 167 & 166 & 165 \\
\hline fat (extract ether) & 61 & 62 & 64 & 59 \\
\hline crude fibre & 40 & 43 & 41 & 43 \\
\hline starch & 460 & 453 & 440 & 450 \\
\hline sugar & 84 & 83 & 88 & 87 \\
\hline \multicolumn{5}{|l|}{ Nutritive value } \\
\hline digestible protein (determined) & 133 & 134 & 131 & 133 \\
\hline lysine $^{2}$ & \multicolumn{4}{|c|}{7.40} \\
\hline methionine $^{2}$ & \multicolumn{4}{|c|}{2.63} \\
\hline threonine $^{2}$ & \multirow{2}{*}{\multicolumn{4}{|c|}{$\begin{array}{l}5.00 \\
1.31\end{array}$}} \\
\hline thrypthofan ${ }^{2}$ & & & & \\
\hline ME, MJ $\mathrm{kg}^{-1}$ (determined) & 13.5 & 13.5 & 13.4 & 13.4 \\
\hline
\end{tabular}

note: data on composition and nutritive value of diets A, B and C are the same as in the study by Wojtasik et al. (2012)

${ }^{1}$ addition of 2.5\% premix introduce to $1 \mathrm{~kg}$ diet: IU: vit.A 1500, vit. $\mathrm{D}_{3} 300$; mg: Fe 60, $\mathrm{NaCl} 3$, Zn 50, Cu 30, Mn 30, J 0.30, Se 0.20; vit. E 150, vit. $K_{3} 2.0$, vit. $B_{1} 2.0$, vit. $B_{2} 2.5$, vit. $B_{6} 2.0$, vit. $\mathrm{B}_{12} 0.02$, biotin 0.11 , folic acid 0.6 , nicotinic acid 15 , calcium-D pantothenate 10 , choline chloride 500; g: Ca 2.8, P 0.07, and essential amino acids: L-lysine-HCl 2.63, DL-methionine 0.68 , L-threonine $0.98 ;{ }^{2}$ standarized ileal digestible amino acids, $\mathrm{g} \mathrm{kg}^{-1}$

Detailed information about diets, animals housing, feeding, and sample preparation are given in Wojtasik et al. (2012).

\section{Calculations and statistical analysis}

The results were analysed using one-way ANOVA. Differences between groups were tested using the Tukey test. Due to the close relation between the animals (litters) and the identical ages at slaughter, the influence of these factors was omitted in the statistical analyses. Gender had no effect on performance or fatty acid profiles, therefore this factor was also omitted in the statistical analyses. 
Table 2. Content of fatty acids in experimental diets, $\mathrm{g} \cdot \mathrm{MJ}^{-1} \mathrm{ME}$

\begin{tabular}{|c|c|c|c|c|}
\hline \multirow{2}{*}{ Fatty acids } & \multicolumn{4}{|c|}{ Diet $^{1}$} \\
\hline & A & B & $\mathrm{C}$ & $\mathrm{D}$ \\
\hline$\overline{\sum F A}$ & 3.68 & 3.70 & 3.98 & 3.88 \\
\hline$\overline{\Sigma S F A}$ & 0.56 & 0.71 & 0.71 & 0.69 \\
\hline $\bar{\Sigma}$ MUFA & 1.29 & 1.24 & 1.13 & 1.12 \\
\hline$\sum$ PUFA & 1.83 & 1.75 & 2.14 & 2.07 \\
\hline$\sum \bar{P} U F A / \sum S F A$ & 3.27 & 2.46 & 3.01 & 3.00 \\
\hline $\mathrm{C} 16: 0$ & 0.435 & 0.536 & 0.522 & 0.508 \\
\hline C16:1 & 0.006 & 0.058 & 0.047 & 0.016 \\
\hline C18:0 & 0.077 & 0.097 & 0.122 & 0.131 \\
\hline C18:1 & 1.233 & 1.037 & 0.913 & 1.040 \\
\hline C18:2 n-6 (LA) & 1.45 & 1.45 & 1.40 & 1.43 \\
\hline C18:3 n-3 (ALA) & 0.38 & 0.17 & 0.67 & 0.63 \\
\hline C20:4 n-6 & nd & nd & nd & nd \\
\hline C20:5 n-3 (EPA) & nd & 0.052 & 0.044 & 0.002 \\
\hline C22:5 n-3 (DPA) & nd & 0.009 & 0.007 & 0.002 \\
\hline C22:6 n-3 (DHA) & nd & 0.069 & 0.057 & 0.011 \\
\hline$\sum n-6$ fatty acids & 1.456 & 1.461 & 1.369 & 1.428 \\
\hline$\sum$ n-3 fatty acids & 0.37 & 0.42 & 0.88 & 0.66 \\
\hline C18:2n-6/C18:3n-3 & 3.87 & 8.38 & 2.05 & 2.25 \\
\hline$\sum n-6 / \sum n-3$ & 3.87 & 4.80 & 1.77 & 2.20 \\
\hline
\end{tabular}

${ }^{1}$ see Table 1; nd - not determined

The relationship between the n-3 PUFA content and chemical components of tissues and between n-3 PUFA intake and content in the investigated tissues was expressed as a linear model according to the following formula:

$$
\mathrm{Y}=\mathrm{a}+\mathrm{b} \times \mathrm{X}
$$

where: $\mathrm{Y}$ - content of ALA, EPA, DHA, or EPA+DPA (g/100 g tissue); a - intercept; b - slope ratio; $X$ - tissue chemical components (g/100 g) or n-3 PUFA intake (g/day).

Statistical analysis was performed using Statgraphics Centurion (version XV2005) software.

\section{RESULTS}

Feed intake, growth rate, and feed conversion ratio (FCR) did not differ significantly among groups of animals (mean $2.51 \mathrm{~kg} / \mathrm{day}, 950 \mathrm{~g} /$ day and 2.64 $\mathrm{kg}$ feed/kg gain, respectively; Table 3). Carcass weight, meat content, backfat thickness, values of $\mathrm{pH}_{45}$ and $\mathrm{pH}_{24}$ were also similar in all groups (mean $81.0 \mathrm{~kg}$, $61.1 \%, 19.9 \mathrm{~mm}, 6.24$ and 5.68, respectively).

Neither weight, intramuscular fat, nor fatty acid contents of the Musculus longissimus dorsi differed significantly among groups of pigs (mean $2396 \mathrm{~g}$, $3.33 \%$ and $2.97 \mathrm{~g} / 100 \mathrm{~g}$ tissue, respectively; Table 4). The SFA, MUFA, PUFA 
Table 3. Performance of animals and carcass characteristic

\begin{tabular}{|c|c|c|c|c|c|c|}
\hline \multirow{2}{*}{ Indices } & \multicolumn{4}{|c|}{ Diet $^{1}$} & \multirow{2}{*}{ SEM } & \multirow{2}{*}{ Significance } \\
\hline & A & B & $\mathrm{C}$ & $\mathrm{D}$ & & \\
\hline Body weight, kg & 105.1 & 103.9 & 104.2 & 104.5 & 0.62 & ns \\
\hline Feed intake, kg/day & 2.51 & 2.51 & 2.50 & 2.51 & 0.011 & ns \\
\hline Daily gain, g & 972 & 953 & 945 & 931 & 24 & ns \\
\hline $\mathrm{FCR}^{2}, \mathrm{~kg}$ feed/kg gain & 2.58 & 2.63 & 2.65 & 2.70 & 0.010 & ns \\
\hline Cold carcass, kg & 81.6 & 80.3 & 81.3 & 80.8 & 0.81 & ns \\
\hline Meat content, \% & 61.7 & 61.5 & 61.2 & 60.1 & 0.79 & ns \\
\hline Backfat thickness ${ }^{3}, \mathrm{~mm}$ & 19.8 & 19.9 & 19.5 & 20.2 & 1.68 & ns \\
\hline pH 45 min & 6.13 & 6.22 & 6.32 & 6.28 & 0.24 & ns \\
\hline $\mathrm{pH} 24 \mathrm{~h}$ & 5.57 & 5.55 & 5.86 & 5.75 & 0.26 & ns \\
\hline
\end{tabular}

${ }^{1}$ see Table $1 ;{ }^{2}$ FCR - feed conversion ratio; ${ }^{3}$ backfat thickness average from 5 measurements (on the neck, over last thoracic vertebra and over beginning, middle and end of the muscle Gluteus medius - on the cross); ns - not significant

Table 4. Weight of the Musculus longissimus dorsi (MLD, g), content of intramuscular fat (IMF, \%) and content of total of fatty acids (FA), SFA, MUFA, PUFA and particular FA in the MLD, g/100 g tissue

\begin{tabular}{|c|c|c|c|c|c|c|}
\hline \multirow{2}{*}{ Indices } & \multicolumn{4}{|c|}{ Diet $^{1}$} & \multirow{2}{*}{ SEM } & \multirow{2}{*}{ Significance } \\
\hline & A & B & $\mathrm{C}$ & $\mathrm{D}$ & & \\
\hline MLD & 2556 & 2368 & 2344 & 2316 & 70.95 & ns \\
\hline IMF & 3.05 & 3.73 & 3.22 & 3.32 & 0.351 & ns \\
\hline$\sum \mathrm{FA}$ & 2.54 & 3.39 & 2.93 & 3.02 & 0.321 & ns \\
\hline$\sum \mathrm{SFA}$ & 1.00 & 1.17 & 1.21 & 1.14 & 0.11 & ns \\
\hline$\sum$ MUFA & 1.15 & 1.50 & 1.20 & 1.26 & 0.14 & ns \\
\hline$\sum$ PUFA & 0.39 & 0.47 & 0.46 & 0.43 & 0.04 & ns \\
\hline$\sum \mathrm{PUFA} / \sum \mathrm{SFA}$ & 0.39 & 0.40 & 0.39 & 0.38 & 0.03 & ns \\
\hline 16:0 & 0.54 & 0.68 & 0.61 & 0.60 & 0.065 & ns \\
\hline $16: 1$ & 0.056 & 0.083 & 0.067 & 0.065 & 0.008 & ns \\
\hline 18:0 & 0.364 & 0.395 & 0.467 & 0.420 & 0.052 & ns \\
\hline $18: 1 \mathrm{n}-9$ & 1.00 & 1.31 & 1.03 & 1.10 & 0.125 & ns \\
\hline $18: 1 \mathrm{n}-7$ & 0.078 & 0.102 & 0.085 & 0.086 & 0.009 & ns \\
\hline $18: 2$ n-6 (LA) & 0.291 & 0.354 & 0.330 & 0.305 & 0.028 & ns \\
\hline $18: 3$ n-3 (ALA) & $0.039^{\mathrm{AB}}$ & $0.030^{\mathrm{A}}$ & $0.059^{\mathrm{B}}$ & $0.056^{\mathrm{B}}$ & 0.007 & $* *$ \\
\hline $20: 4 n-6$ & 0.017 & 0.024 & 0.025 & 0.022 & 0.004 & ns \\
\hline 20:5 n-3(EPA) & 0.014 & 0.018 & 0.015 & 0.017 & 0.001 & ns \\
\hline 22:5 n-3 (DPA) & 0.019 & 0.024 & 0.020 & 0.021 & 0.002 & ns \\
\hline 22:6 n-3 (DHA) & 0.008 & 0.015 & 0.009 & 0.011 & 0.003 & ns \\
\hline$\sum \mathrm{n}-6$ fatty acids & 0.308 & 0.379 & 0.355 & 0.328 & 0.031 & ns \\
\hline$\sum \mathrm{n}-3$ fatty acids & 0.081 & 0.087 & 0.103 & 0.104 & 0.009 & ns \\
\hline $18: 2 n-6 / 18: 3 n-3$ & $7.46^{\mathrm{A}}$ & $11.80^{\mathrm{B}}$ & $5.59^{\mathrm{A}}$ & $5.45^{\mathrm{A}}$ & 0.761 & ** \\
\hline$\sum \mathrm{n}-6 / \sum \mathrm{n}-3$ & $3.82^{\mathrm{AB}}$ & $4.45^{\mathrm{B}}$ & $3.50^{\mathrm{AB}}$ & $3,15^{\mathrm{A}}$ & 0.240 & $* *$ \\
\hline
\end{tabular}

${ }^{1}$ see Table 1 ; ${ }^{\text {A, B }}$ - means within the same line with no common superscripts differ at $\mathrm{P}<0.01$; ** - value marked different letter differ significantly at $\mathrm{P}<0.01$; ns - not significant

contents and PUFA/SFA ratios were also similar among groups (mean 1.13, 1.28, $0.44 \mathrm{~g} / 100 \mathrm{~g}$ tissue and 0.39 , respectively). The content of individual fatty acids also did not differ among the animals, except $\mathrm{C} 18: 3 \mathrm{n}-3$, which differed significantly $(\mathrm{P}<0.01)$ among groups and equaled in increasing order: 0.030 (group $\mathrm{B}), 0.039$ (group A), 0.056 (group D), and 0.059 (group C); the differences were significant 
only between group $B(0.030)$ and groups $C$ and D (mean 0.058). The C18:2 n-6/ C18:3 n-3 ratio differed $(\mathrm{P}<0.01)$ among animals of groups $\mathrm{A}, \mathrm{C}, \mathrm{D}$, and $\mathrm{B}$ (mean 6.17 vs 11.8 ). However, when the ratios of the sum of $n-6$ and $n-3$ fatty acids were compared, this value was the lowest in animals of group D (3.15), higher in pigs of groups A and C (mean 3.66), and the highest in group B (4.45).

Backfat weight, fat concentration, and total fatty acid concentration in fat tissue also did not differ among groups (mean $4270 \mathrm{~g}, 74.9 \%, 67.3 \mathrm{~g} / 100 \mathrm{~g}$ tissue, respectively; Table 5). The SFA and MUFA contents were also similar in all groups (mean 24.79, $26.53 \mathrm{~g} / 100 \mathrm{~g}$ tissue, respectively for SFA, MUFA).

Table 5. Weight of the backfat (BF, g), fat in the backfat (fat, \%) and content of total of fatty acids (FA), SFA, MUFA, PUFA and particular FA in the BF, g/100 g tissue

\begin{tabular}{|c|c|c|c|c|c|c|}
\hline \multirow{2}{*}{ Indices } & \multicolumn{4}{|c|}{ Diet $^{1}$} & \multirow{2}{*}{ SEM } & \multirow{2}{*}{ Significance } \\
\hline & A & B & $\mathrm{C}$ & $\mathrm{D}$ & & \\
\hline Backfat & 4114 & 4043 & 4202 & 4721 & 286 & ns \\
\hline Fat & 74.00 & 76.10 & 75.50 & 74.00 & 1.40 & ns \\
\hline$\sum \mathrm{FA}$ & 66.7 & 69.2 & 66.7 & 66.7 & 210 & ns \\
\hline$\sum \mathrm{SFA}$ & 23.9 & 26.0 & 24.8 & 24.4 & 0.70 & ns \\
\hline$\sum$ MUFA & 26.7 & 27.6 & 26.3 & 25.5 & 0.62 & ns \\
\hline$\sum$ PUFA & $15.3^{\mathrm{AB}}$ & $13.9^{\mathrm{A}}$ & $16.0^{\mathrm{B}}$ & $16.8^{\mathrm{B}}$ & 0.39 & ** \\
\hline$\sum \mathrm{PUFA} / \sum \mathrm{SFA}$ & $0.65^{\mathrm{B}}$ & $0.54^{\mathrm{A}}$ & $0.64^{\mathrm{B}}$ & $0.69^{\mathrm{B}}$ & 0.02 & ** \\
\hline $16: 0$ & 13.62 & 14.82 & 14.10 & 13.78 & 0.42 & ns \\
\hline $16: 1$ & 0.92 & 1.19 & 1.06 & 0.99 & 0.07 & ns \\
\hline $18: 0$ & 9.07 & 9.45 & 9.48 & 9.84 & 0.29 & ns \\
\hline $18: 1 \mathrm{n}-9$ & 23.36 & 23.44 & 22.52 & 22.58 & 0.56 & ns \\
\hline $18: 1 \mathrm{n}-7$ & 1.47 & 1.68 & 1.56 & 1.45 & 0.06 & ns \\
\hline $18: 2 \mathrm{n}-6$ (LA) & 12.16 & 11.33 & 11.68 & 12.26 & 0.30 & ns \\
\hline $18: 3$ n-3 (ALA) & $2.24^{\mathrm{B}}$ & $1.37^{\mathrm{A}}$ & $3.28^{\mathrm{C}}$ & $3.73^{\mathrm{D}}$ & 0.08 & $* *$ \\
\hline $20: 4 n-6$ & 0.12 & 0.12 & 0.09 & 0.09 & 0.11 & ns \\
\hline 20:5 n-3(EPA) & $0.04^{\mathrm{A}}$ & $0.13^{\mathrm{B}}$ & $0.12^{\mathrm{B}}$ & $0.07^{\mathrm{A}}$ & 0.01 & ** \\
\hline 22:5 n-3 (DPA) & $0.10^{\mathrm{A}}$ & $0.28^{\mathrm{B}}$ & $0.23^{\mathrm{B}}$ & $0.11^{\mathrm{A}}$ & 0.015 & $* *$ \\
\hline 22:6 n-3 (DHA) & $0.06^{\mathrm{A}}$ & $0.31^{\mathrm{B}}$ & $0.21^{\mathrm{B}}$ & $0.07^{\mathrm{A}}$ & 0.015 & $* *$ \\
\hline$\sum \mathrm{n}-6$ fatty acids & 12.94 & 12.03 & 12.32 & 12.89 & 0.31 & ns \\
\hline$\sum \mathrm{n}-3$ fatty acids & $2.51^{\mathrm{A}}$ & $2.15^{\mathrm{A}}$ & $3.91^{\mathrm{B}}$ & $4.04^{\mathrm{B}}$ & 0.11 & ** \\
\hline $18: 2 n-6 / 18: 3 n-3$ & $5.45^{\mathrm{B}}$ & $8.33^{\mathrm{C}}$ & $3.57^{\mathrm{A}}$ & $3.28^{\mathrm{A}}$ & 0.10 & ** \\
\hline$\sum \mathrm{n}-6 / \sum \mathrm{n}-3$ & $5.18^{\mathrm{B}}$ & $5.60^{\mathrm{C}}$ & $3.17^{\mathrm{A}}$ & $3.19^{\mathrm{A}}$ & 0.10 & ** \\
\hline
\end{tabular}

${ }^{1}$ see Table $1{ }^{\mathrm{A}, \mathrm{B}}$ - means within the same line with no common superscripts differ at $\mathrm{P}<0.01$ ** - value marked different letter differed significantly at $\mathrm{P}<0.01$; ns - non significant

The PUFA content ranged from $13.9 \mathrm{~g} / 100 \mathrm{~g}$ tissue (group B) to $16.8 \mathrm{~g} / 100 \mathrm{~g}$ tissue (group D), but a significant difference $(\mathrm{P}<0.01)$ was found only between animals in group $\mathrm{B}$ and those in groups $\mathrm{C}$ and $\mathrm{D}$. The PUFA/SFA ratio was similar in pigs of groups $\mathrm{A}, \mathrm{C}$, and $\mathrm{D}$ and was greater than in group $\mathrm{B}$ (mean 0.66 vs $0.54 ; \mathrm{P}<0.01)$. The content of $\mathrm{C} 18: 3 \mathrm{n}-3$ acid differed $(\mathrm{P}<0.01)$ among all groups and ranged from $1.37 \mathrm{~g} / 100 \mathrm{~g}$ tissue (group B) to $3.73 \mathrm{~g} / 100 \mathrm{~g}$ tissue (group D). The content of all long-chain n-3 PUFA took the same arrangement as content of this group of fatty acids was lower $(\mathrm{P}<0.01)$ in animals of group $\mathrm{A}$ and D compared with pigs of groups $\mathrm{B}$ and $\mathrm{C}$. The content of n-3 PUFA 
was lower in animals of groups A and B compared with $\mathrm{C}$ and $\mathrm{D}$ (mean 2.33 vs $3.97 \mathrm{~g} / 100 \mathrm{~g}$ tissue; $\mathrm{P}<0.05)$. The ratios of $18: 2 \mathrm{n}-6 / 18: 3 \mathrm{n}-3$ and $\sum \mathrm{n}-6 / \sum \mathrm{n}-3$ differed significantly $(\mathrm{P}<0.01)$ among treatments and reached the lowest values in groups $\mathrm{C}$ and D (mean 3.44 and 3.18, respectively) and the highest in the animals of group B (8.33 and 5.60, respectively).

The relationship between the content (g/100 g tissue) of long-chain n-3 PUFA and that of fat in the investigated tissues was determined on the basis of the data from ' 0 ' and experimental animals (Table 6). The correlation coefficients ranged from 0.45 (for C20:5 n-3) to 0.60 (for C18:3 n-3). Moreover, a linear relation was found between the intake of C18:3 n-3 and its content in both meat and backfat (Table 7), although a stronger correlation was found for backfat $(r=0.85)$ than

Table 6. Relationship $(\mathrm{Y}=\mathrm{a}+\mathrm{b} \times \mathrm{X})$ between content of intramuscular fat of Musculus longissimus dorsi and content of long-chain PUFA n-3 $(n=36)$

\begin{tabular}{lccccc}
\hline $\begin{array}{l}\text { Fatty acid content } \\
\text { g/100 g }(Y)\end{array}$ & $\mathrm{a}$ & $\mathrm{b}$ & $\begin{array}{c}\text { Chemical } \\
\text { component } \\
\mathrm{g} / 100 \mathrm{~g}(\mathrm{X})\end{array}$ & $\mathrm{r}$ & Significance \\
\hline $\mathrm{C} 18: 3 \mathrm{n}-3(\mathrm{ALA})$ & $-0.006( \pm 0.019)$ & $0.04( \pm 0.015)$ & IMF & 0.60 & $* *$ \\
C20:5 n-3 (EPA) & $0.009( \pm 0.003)$ & $0.002( \pm 0.001)$ & IMF & 0.45 & $* *$ \\
C22:5 n-3 (DPA) & $0.011( \pm 0.004)$ & $0.003( \pm 0.001)$ & IMF & 0.49 & $* *$ \\
C22:6 n-3 (DHA) & $0.006( \pm 0.002)$ & $0.004( \pm 0.001)$ & IMF & 0.51 & $* *$ \\
C20:5 n-3 + C22:6 n-3 & $0.005( \pm 0.006)$ & $0.006( \pm 0.002)$ & IMF & 0.54 & $* *$ \\
\hline
\end{tabular}

** at $\mathrm{P}<0.01$

Table 7. Relationship $(\mathrm{Y}=\mathrm{a}+\mathrm{b} \times \mathrm{X})$ between intake of long-chain PUFA $\mathrm{n}-3$ and their content in investigated tissues $(\mathrm{n}=32)$

\begin{tabular}{|c|c|c|c|c|c|}
\hline $\begin{array}{l}\text { Fatty acid content, } \\
\mathrm{g} / 100 \mathrm{~g}(\mathrm{Y})\end{array}$ & $\mathrm{a}$ & b & $\begin{array}{c}\text { Fatty acid intake } \\
\text { g/day }(X)\end{array}$ & $r$ & Significance \\
\hline \multicolumn{6}{|c|}{ Longissimus dorsi muscle } \\
\hline C18:3 n-3 (ALA) & $0.013( \pm 0.009)$ & $0.002( \pm 0.0005)$ & C18:3 n-3 (ALA) & 0.59 & $* * *$ \\
\hline C20:5 n-3 (EPA) & $0.015( \pm 0.001)$ & $0.001( \pm 0.0009)$ & C20:5 n-3 (EPA) & 0.23 & ns \\
\hline C22:5 n-3 (DPA) & $0.020( \pm 0.001)$ & $0.012( \pm 0.007)$ & C22:5 n-3 (DPA) & 0.31 & ns \\
\hline C22:6 n-3 (DHA) & $0.009( \pm 0.002)$ & $0.002( \pm 0.0011)$ & C22:6 n-3 (DHA) & 0.27 & ns \\
\hline $\begin{array}{l}\text { C20:5 n-3 + C22:6 n-3 } \\
\text { (EPA+DHA) }\end{array}$ & $0.024( \pm 0.0024)$ & $0.001( \pm 0.0009)$ & $\begin{array}{l}\text { C20:5 n-3 + C22:6 n-3 } \\
\text { (EPA+DHA) }\end{array}$ & 0.20 & ns \\
\hline \multicolumn{6}{|l|}{ Backfat } \\
\hline C18:3 n-3 (ALA) & $0.409( \pm 0.289)$ & $0.127( \pm 0.016)$ & C18:3 n-3 (ALA) & 0.85 & $* * *$ \\
\hline C20:5 n-3 (EPA) & $0.066( \pm 0.009)$ & $0.035( \pm 0.008)$ & C20:5 n-3 (EPA) & 0.64 & $* * *$ \\
\hline C22:5 n-3 (DPA) & $0.111( \pm 0.011)$ & $0.555( \pm 0.064)$ & C22:5 n-3 (DPA) & 0.87 & $* * *$ \\
\hline C22: 6n-3 (DHA) & $0.039( \pm 0.013)$ & $0.089( \pm 0.009)$ & C22:6 n-3 (DHA) & 0.89 & $* * *$ \\
\hline $\begin{array}{l}\text { C20:5 n-3 + C22:6 n-3 } \\
\text { (EPA+DHA) }\end{array}$ & $0.134( \pm 0.020)$ & $0.066( \pm 0.008)$ & $\begin{array}{l}\mathrm{C} 20: 5 \mathrm{n}-3+\mathrm{C} 22: 6 \mathrm{n}-3 \\
\text { (EPA+DHA) }\end{array}$ & 0.85 & $* * *$ \\
\hline
\end{tabular}


MLD ( $r=0.59)$. As for the remaining long-chain n-3 PUFA, a linear relationship between their intake and tissue concentration was found only in backfat (the correlations ranged from 0.64 for $\mathrm{C} 20: 5$ n-3 to 0.89 for C22:6 n-3).

\section{DISCUSSION}

As expected, supplementation of diets with different fat mixtures did not change the nutritional value or energy content in the diets and, consequently, did not influence the performance of animals or carcass parameters. Also, in keeping with our assumptions, the animals did not differ in SFA, MUFA, or n-6 PUFA contents. Our results showed that the influence of fat source on fatty acid composition was most evidenced in tissues characterized by a greater fat content. In the Musculus longissimus dorsi, the fat supplements changed only the content of C18:3, n-3 but the remaining long-chain n-3 PUFA were unchanged. In backfat, however, both C18:3 n-3 and the other long-chain n-3 PUFA were also changed. Addition of a mixture of linseed oil and fish oil as well as rapeseed oil significantly increased the content of C18:3 n-3 in both investigated tissues. The decisive factor was the use of linseed oil as the main component of both mixtures, as it is the source of the greatest amount of linolenic acid (Flachowsky et al., 2008; Więcek et al., 2010). Beneficial effects of linseed oil added to feed for pigs and other species (e.g., turkeys or chickens) on the fatty acid profile of animal tissues (Nguyen et al., 2003a; Jankowski et al., 2012; Poławska et al., 2012) and content (Raj et al., 2010) have also been demonstrated by other authors. In our study, the experimental treatment influenced the content $(\mathrm{g} / 100 \mathrm{~g}$ tissue) of long-chain n-3 PUFA only in the backfat. This was a result of adding fish oil to feed fat mixtures, as it is the carrier of a large number of long-chain n-3 PUFA (Raj et al., 2010; Wojtasik et al., 2012). This means that these fatty acids were deposited in animal tissue directly from the feed. The presence of long-chain n-3 PUFA in backfat was also observed in a group of animals fed a diet that did not contain fish oil. These animals, however, received feed supplemented with linseed oil containing a large amount of linolenic acid, which may be converted into longchain n-3 PUFA by $\Delta 4, \Delta 5$, and $\Delta 6$ - desaturases and elongases (Raes et al., 2004; Kouba and Sellier, 2011).

We found only the studies by Lizardo et al. (2002) and Kloareg et al. (2007) in which the relation between nutrient intake and content of fatty acids in the whole body was investigated. Our results are similar to those presented by these authors. Nonetheless, when the concentration/profile of $n-3$ fatty acids (EPA, DPA and DHA) is considered (e.g., Kouba et al., 2003) they are easier to improve in intramuscular fat than in backfat. Moreover, according to the same authors, it is easier to change C18:3 n-3 and C18:2 n-6 in backfat than in meat. 
The Regulation of the European Commission (No. 116/2010; 2010) states that food can be considered a source of n-3 PUFA if the product contains at least $300 \mathrm{mg} / 100 \mathrm{~g}$ of linolenic acid and a total of $40 \mathrm{mg} / 100 \mathrm{~g}$ of eicosapentaenoic and docosahexaenoic acids. Foods with a high content of n-3 fatty acids must contain at least $600 \mathrm{mg} / 100 \mathrm{~g}$ of linolenic acid and a total of at least $100 \mathrm{mg} / 100 \mathrm{~g}$ of eicosapentaenoic and docosahexaenoic acids, but it is sufficient if a product fulfills only one of these recommendations (i.e., for only ALA or EPA plus DHA). Taking these needs into consideration in the experimental treatments used in our study did not result in achieving the recommended values in the Musculus longissimus dorsi. Despite using fat mixtures containing a large amount of long-chain n-3 PUFA (or their precursors), the sum of eicosapentaenoic and docosahexaenoic acids in the MLD reached only slightly more than half of the amount required for a product to be considered a source of $n-3$ fatty acids. In the case of C18:3n-3, the achieved amount was only $20 \%$ of the recommended value in the best groups fed a diet containing linseed and fish oil or linseed and rapeseed oil. The ALA content in the backfat did, however, repeatedly exceed the values recommended for products with a high content of n-3 fatty acids. The content of other n-3 PUFA in this tissue reached values recommended for food being a source of EPA and DHA in the group of pigs fed mixtures of rapeseed and fish oils or linseed and fish oils. Moreover, in the backfat of pigs fed a diet with a mixture of linseed and fish oils, the content of EPA and DHA reached almost $90 \%$ of the value recommended for products that are a source of n- 3 fatty acids. It seems that fat content plays the crucial role since our data indicate that there is a positive correlation between the content of $n-3$ fatty acids and fat content in the investigated muscle. This means that an increase in the fat content of the tissue increases the contribution ( $\mathrm{g} / 100 \mathrm{~g}$ ) of these fatty acids. Based on calculations using the regression equations presented in this work, it seems that for the content of C18:3 n-3 and C20:5 n-3 and C22:6 n-3 acids in the meat to reach the value recommended for a product being a source of these fatty acids, the intramuscular fat content should be 7.6 and 6.0 $\mathrm{g} / 100 \mathrm{~g}$, respectively. For the meat product to a high source of these acids, the intramuscular fat content would have to be 15.1 and $15.8 \mathrm{~g} / 100 \mathrm{~g}$, respectively. Obviously, such a high intramuscular fat content in pigs (and other domestic species) is impossible to reach, even using nutritional manipulation. In the available literature no data was found approaching the issue in this way. Therefore, a discussion of these results is difficult to carry out.

Only a few researchers have tried to determine the mathematical relationship between n-3 PUFA intake and its concentration in body tissues. Moreover, their studies focused on determining the relationship between intake or concentration in feed (Nguyen et al., 2003b; Falchowsky et al., 2008) of fatty acids and the profile of examined tissues. Our research involved determining the mathematical 
relationship between intake of long-chain n-3 PUFA and their quantitative content in consumer products like fresh meat (backfat is generally seen as unhealthy). A strong linear relationship was found between intake of C18:3n-3 and its content in both investigated tissues, however, a stronger correlation was found in backfat. Falchowsky et al. (2008) also found a linear relationship between the intake of polyenic fatty acids and their percentage share in the MLD, although, similarly to our results, the correlation coefficient was small. Our data showed that in the case of C20:5 n-3 and C22:6 n-3, a strong linear relation existed only for backfat. Our data indicate that increasing the daily intake of C18:3 n-3 by $1 \mathrm{~g}$ increases its content in meat by less than $0.02 \mathrm{~g} / 100 \mathrm{~g}$ tissue and in the backfat, by $0.53 \mathrm{~g} / 100 \mathrm{~g}$ tissue. This means that incorporation of ALA into meat is several dozen times less effective than into backfat. We also found no relationship between total EPA and DHA intake and their content in the meat, whereas in backfat, increasing the intake of these acids by $1 \mathrm{~g}$ increases their content by $0.2 \mathrm{~g}$. Generally, determining the relationships between intake of long-chain n-3 PUFA and their content in leaner tissues is much more difficult than in fatty ones due to the strong relationship between fatty acid contents and fat concentrations in the tissue, which was mentioned above.

Nguyen et al. (2003b) also found a linear relationship between feed intake of C18:3 n-3, C20:5 n-3, and C22:6 n-3 acids and their concentration/profile in adipose tissue. Similarly to our results, these authors found that docosahexaenoic acid is more efficiently incorporated into adipose tissue than eicosapentaenoic acid. They claimed that this is caused by differences in the susceptibility of the latter to biochemical conversion.

Some of the suggestions made by Nguyen et al. (2003b) are in contradiction to ours, however, because they claim that linolenic acid is more efficiently incorporated into intramuscular fat than adipose fat. The discrepancy between these two studies could be due to Nguyen et al. (2003b) basing their conclusion only on calculations of literature data.

\section{CONCLUSIONS}

It is concluded that the relatonship between intake and fat contents of longchain n-3 PUFA in pigs is more evidenced in the backfat than in intramuscular fat. Improving the n-3 PUFA content in meat to values recommended for products that are a source of these fatty acids is difficult to attain, since it would require an increase in the intramuscular fat content to levels much exceeding current dietary guidelines. 


\section{REFERENCES}

AOAC, 2005. Association of Official Analytical Chemists, Official Methods of Analysis. $18^{\text {th }}$ Edition. Arlington, VA

Commission Regulation (EU) No 116/2010 of 9 February 2010

Enser M., Hallett K., Hewitt B., Fursey G.A.J., Wood J.D., 1996. Fatty acid content and composition of Engish beef, lamb and pork at retail. Meat Sci. 42, 443-456

Flachowsky G., Schulz E., Kratz R., Glodek P., 2008. Effect of different dietary fat sources on the fatty acid profile of backfat and intramuscular fat of pigs of various sire breeds. J. Anim. Feed Sci. 17, 363-371

Folch J., Lees M., Stanley G.H.S., 1957. A simple method for the isolation and purification of lipids from animal tissues. J. Biol. Chem. 226, 497-509

Haak L., De Smet S., Fremaut D., Van Walleghem K., Raes K., 2008. Fatty acid profile and oxidative stability of pork as influenced by duration and time of dietary linseed or fish oil supplementation. J. Anim. Sci. 86, 1418-1425

Jankowski J., Zduńczyk P., Mikulski D., Juśkiewicz J., Mikulska M., Zduńczyk Z., 2012. Effects of dietary soyabean, rapeseed and linseed oils on performance, slaughter yied and fatty acid profile of breast meat in turkeys. J. Anim. Feed Sci. 21, 143-156

Jaturasitha S., Khiaosa-ard R., Pongpiachan P., Kreuzer M., 2009. Early deposition of n-3 fatty acids from tuna oil in lean and adipose tissue of fattening pigs is mainly permanent. J. Anim. Sci. 87, 693-703

Kloareg M., Noblet J., van Milgen J., 2007. Deposition of dietary fatty acids, de novo synthesis and anatonical partitioning of fatty acids in finishing pigs. Brit. J. Nutr. 97, 35-44

Kouba M., Enser M., Whittington F.M., Nute G.R., Wood J.D., 2003. Effect of a high-linolenic acid diet on lipogenic enzyme activities, fatty acid composition, and meat quality in the growing pig. J. Anim. Sci. 81, 1967-1979

Kouba M., Sellier P., 2011. A review of the factors influencing the development of intermuscular adipose tissue in the growing pig. Meat Sci. 88, 213-220

Kratz R., 2003. Einfluss unterschiedlicher Fettquellen in der Ernährung von Schweinen unterschiedlicher Genetik auf den Protein-und Lipidansatz, das Fettsaurenmuster verschiedener Teilstucke und die Fleischbeschaffenheit. Diss. Gießen. Proc. Soc. Nutr. Physiol. 14, 207-213

Lizardo R., Van Milgen J., Mourot J., Noblet J., Bonneau M., 2002. A nutritional model of fatty acid composition in the growing-finishing pig. Livest. Prod. Sci. 75, 167-182

Nguyen C.V., Smulikowska S., Mieczkowska A., 2003b. Effect of linseed and rapeseed or linseed and rapeseed oil on performance, slaughter yield and fatty acid deposition in edible parts of the carcass in broiler chickens. J. Anim. Feed Sci. 12, 271-288

Nguyen L.Q., Nuijens M.C.G.A., Everts H., Salden N., Beynen A.C., 2003a. Mathematical relationship between the intake of n- 6 and n-3 polyunsaturated fatty acids and their contents in adipose tissue of growing pigs. Meat Sci. 65, 1399-1406

Poławska E., Lisiak D., Jóźwik A., Pierzchała M., Strzałkowska N., Pomianowski J., Wójcik A., 2012. The effect of the diet supplementation with linseed and rapeseed on the physic-chemical and sensory characteristics of ostrich meat. Anim. Sci. Pap. Rep. 30, 65-72

Raes K., De Smet S., Demeyer D., 2004. Effect of dietary fatty acids on incorporation of long chain polyunsaturated fatty acids and conjugated linoleic acid in lamb, beef and pork meat: a review. Anim. Feed Sci. Tech. 113, 199-221

Raj S., Poławska E., Skiba G., Weremko D., Fandrejewski H., Skomiał J., 2010. The influence of different fatty acids sources in diets on chemical composition of the body and utilisation of linoleic and linolenic acids in pigs. Anim. Sci. Pap. Rep. 28, 355-362

Simopoulos A.P., 2001. Fatty acids and human health: defining strategies for public policy. Lipids $36,83-89$ 
WHO/FAO, 2003. Diet nutrition and the prevent of chronic diseases. Report of a Joint WHO/FAO Expert Consultation. WHO Technical Report Series 916. Geneva

Więcek J., Rekiel A., Skomiał J., 2010. Effect of feeding level and linseed oil on some metabolic and hormonal parameters and on fatty acid profile of meat and fat in growing pigs. Arch. Anim. Nutr. 53, 37-49

Wojtasik M., Raj S., Skiba G., Weremko D., Czauderna M., 2012. Effects of diets enriched in the omega-3 fatty acids on the carcass characteristic and fatty acid profile on intramuscular and subcutaneous fat in pigs. J. Anim. Feed Sci. 21, 635-647 